\title{
The largest specimen of Apateon and the life history pathway of neoteny in the Paleozoic temnospondyl family Branchiosauridae
}

\author{
Nadia B. Fröbisch ${ }^{*}, 1$ and Rainer R. Schoch ${ }^{2}$ \\ 1 Redpath Museum, McGill University, Montreal, Canada; Current address: Department of Biology, University of Toronto \\ Mississauga, 3359 Mississauga Road, Mississauga, Ontario L5L 1C6, Canada; E-mail: nadia.frobisch@utoronto.ca \\ 2 Staatliches Museum für Naturkunde Stuttgart, Rosenstein1, 70191 Stuttgart; Germany
}

\begin{abstract}
Received 9 June 2008

Accepted 19 September 2008

Published 20 February 2009

\section{Key Words}

paedomorphosis

metamorphosis

development

phenotypic plasticity

Carboniferous

Permian

Two distinct developmental trajectories, metamorphosis and neoteny (the retention of larval somatic features in adult animals), have been reported for the small gill-bearing branchiosaurids of the Late Carboniferous and Early Permian of central Europe. Based on a very large specimen of the species Apateon caducus (Ammon, 1889), anatomical features characteristic for the neotenic phenotype of branchiosaurids are described. Large neotenes lack changes that occur during a short phase of transformation into terrestrial adults (metamorphosis), such as ossification of the braincase and palatoquadrate and intercentra, further ossification of the girdles and formation of muscle attachment scars and processes on the limb bones. They also lack a distinct sculpturing of the dermal skull roofing elements with deep polygonal ridges and grooves. Instead, larval somatic features are retained including ossified branchial denticles indicative of open gill slits and accentuated larval-type sculpturing of the dermal skull roof. Large size, high degree of ossification as compared to the larvae, and the presence of uncinate processes on the ribs clearly demonstrate an adult ontogenetic stage. Neotenes remained in the aquatic environment throughout their life and were most likely not capable of effective terrestrial locomotion. The frequency distribution of the two phenotypes in modern salamander populations and the environmental cues that influence the development of them provide a comparative framework for the discussion of the evolution of the two life history pathways in branchiosaurids.
\end{abstract}

\section{Introduction}

The small, gill-bearing Branchiosauridae represent the best-known clade within the diverse dissorophoid amphibians of the Late Carboniferous and Early Permian. They are particularly abundant in the fossil lake deposits of central Europe and their fossil record is exceptional due to the Lagerstätten conditions of these localities and with assemblages of hundreds of specimens representing various ontogenetic stages. Moreover, features of their soft anatomy, such as the external gills and 'skin shadows' are preserved in numerous specimens. Based on this excellent fossil record many aspects of the ecology (Boy 1998; Boy \& Sues 2000; Werneburg 2002; Boy 2003), paleogeography (Werneburg \& Schneider 2006), ontogeny (Boy 1971, 1972,
1974; Milner 1982; Boy 1986, 1987; Schoch 1992, 1995; Boy \& Sues 2000; Schoch 2002a; Schoch \& Carroll 2003; Schoch 2004; Fröbisch et al. 2007), and phylogeny (Schoch \& Milner 2008) of branchiosaurids have been analyzed.

Despite the numbers of available specimens and knowledge of many aspects of branchiosaurid biology, it remained unresolved until recently whether branchiosaurids represent larvae of animals that eventually metamorphosed into terrestrial adults or if they were neotenic forms. The term neoteny (or 'paedomorphosis') is here used with reference to the retention of larval somatic features in sexually mature adults.

The vast majority of branchiosaurid specimens represent larval or perennibranchiate forms, and they have been interpreted as neotenic. However, it has also been

\footnotetext{
* Corresponding author
} 
suggested that the absence of metamorphosed adults that would have visited the lakes only seasonally for mating, could be a result of the incomplete fossil record, because very few specimens are known from the shoreline or near shore terrestrial environment (Boy \& Sues 2000). Recently, specimens of the species Apateon gracilis (Credner, 1881), a small taxon that grew to ca. $22 \mathrm{~mm}$ in skull length and is exclusively known from the Niederhäslich locality near Dresden, were identified that clearly represent metamorphosed adults (Boy 1987; Werneburg 1991). Based on a detailed analysis of the ontogenetic sequence of this taxon, we were able to demonstrate that the complete developmental trajectories observable in modern salamanders, i.e. neoteny and metamorphosis, were established in branchiosaurids (Schoch \& Fröbisch 2006). Three distinct phases in the development of Apateon gracilis were recognized: (1) An early larval phase of steadily increasing bone count, (2) a phase of stagnation where no additional developmental events took pace, but rather an overall increase in size occured, and (3) a short phase in which new events occurred in rapid succession which are associated with a switch to a terrestrial habitat (metamorphosis). The findings showed that the tempo and mode of metamorphosis is comparable to modern amphibians and represents the first evidence for a condensed metamorphosis outside the Lissamphibia.

Schoch \& Fröbisch (2006) discussed general aspects of the neotenic trajectory in branchiosaurids. Here we discuss the biological background and the available morphological evidence for neoteny in branchiosaurids in more detail, based on a previously undescribed, wellpreserved specimen of a large Apateon caducus with a skull length of $38 \mathrm{~mm}$ from the Niederkirchen locality in the Saar-Nahe region of western Germany (Figs 1, 2, 3B, C). Apateon caducus was previously known from specimens reaching a skull length of $24 \mathrm{~mm}$ (Fig. 3A) and like the smaller Apateon pedestris Meyer, 1844, was widespread in the lakes of the Palatinate and Autun.

\section{Neoteny in modern salamanders}

Observations on the life history trajectories in branchiosaurids are best compared to modern salamanders, which are considered the most plesiomorphic of all extant amphibians in terms of their morphology and life history (Duellman \& Trueb 1986). They lack the highly specialized tadpole larva of anurans and the highly modified life cycles of caecilians.

Neotenic and metamorphic morphs of a single salamander species are a classic example for phenotypic plasticity, the ability of an individual organism to alter its phenotype in response to changes in environmental conditions. It has frequently been suggested that phenotypic plasticity is evolutionarily adaptive in many taxa (West-Eberhard 2003) and more specifically with reference to neotenic and metamorphosing morphotypes in salamanders, based on observations on the ecology of investigated salamander taxa (Sprules 1974; Whiteman 1994).

In modern salamanders, neoteny varies from obligatorily neotenic forms, e.g. the Mexican axolotl Ambystoma mexicanum (Shaw \& Nodder, 1789), where no members of the species metamorphose under natural conditions, to facultatively neotenic forms, e.g. the tiger salamander Ambystoma tigrinum (Green, 1825) or the red-spotted newt Notophthalmus viridescens (Rafinesque, 1820). Obligatory neoteny arises when the frequency of this morphotype increases under long-term stable environmental conditions and eventually becomes fixed (Whiteman 1994). While present in many salamander taxa (Duellman \& Trueb 1986), facultative neoteny has been particularly well studied for various species and populations of Ambystoma. Neoteny is considered to be triggered by a multitude of factors, such as food availability, population density, size composition of a larval population, presence of predators, presence of parasites or pathogens, and the specific terrestrial and aquatic conditions, whereas either a single factor or a combination of factors can act on different populations (Snyder 1956; Anderson 1971; Wilbur \& Collins 1973; Sprules 1974; Patterson 1978; Semlitsch \& Gibbons 1985; Harris 1987, 1989; Harris et al. 1990; Semlitsch et al. 1990; Whiteman 1994; Shaffer \& Voss 1996). In particular harsh terrestrial conditions, such as severe temperature fluctuations, lack of cover, and low humidity, as well as the availability of permanent bodies of water are considered to play a major role in the occurrence of neotenic morphotypes (Snyder 1956; Sprules 1974; Whiteman 1994). These are often encountered in high altitudes and Ambystoma populations in mountainous regions were found to develop neotenes most frequently (Snyder 1956; Sprules 1974; Whiteman 1994). Nonetheless, even in completely neotenic populations evidence suggests that metamorphosis can be induced when aquatic conditions become very unfavorable as reflected in evaporation rate, salinity, oxygen content, and temperature (Sprules 1974). In other populations, neotenic and metamorphosing individuals coexist in the same ponds and their relative frequency depends on the local environmental parameters (Sprules 1974; Whiteman 1994; Denoel et al. 2002).

Whiteman (1994) formulated three hypotheses to explain the occurrence and frequency distribution of neotenes in modern salamander populations:

(1) The neotenic advantage hypothesis explains the presence of neotenic morphotypes in favorable aquatic habitats. Therein, neotenes have an advantage over metamorphosing morphs if the terrestrial conditions are harsh. The capacity for metamorphosis may still be maintained in these populations if the aquatic conditions are occasionally unfavorable, e.g. in particularly dry years where most or all water of the pond/lake evaporates.

(2) The 'best of a bad lot' hypothesis is the opposite of the neotenic advantage hypothesis. Therein larvae 
within a population that manage to reach a minimal body size for metamorphosis metamorphose into terrestrial adults, while the smaller larvae become neotenes and thereby can reproduce at a smaller body size, making the 'best of a bad lot'.

(3) Finally, the dimorphic neotene hypothesis represents a combination of the two hypotheses outlined above. It is possible that both conditions meet and produce two types of neotenes in the same population. The largest and the smallest larvae become neotenic, while medium-sized larvae metamorphose. Therefore, similar life history mechanisms are favored for different reasons.

This shows that neoteny in salamanders is a result of a complex interplay of environmental conditions resulting in different frequencies of the two life history strategies. Changes in the population structure have also been observed over time. Tihen (1942) investigated a fossil colony of Ambystoma tigrinum in a late Pleistocene sink in Kansas. The Pleistocene population consisted predominantly of neotenic animals, coinciding with harsh terrestrial conditions that have been reconstructed for this locality in the Pleistocene. In contrast, the terrestrial conditions are much more favorable for salamanders today and Ambystoma tigrinum populations in this area nowadays consist predominantly of metamorphosing individuals. Given the complexity of factors influencing the frequency of the two phenotypes, it is not surprising that neotenic morphotypes were found to have evolved independently multiple times in salamanders (Shaffer 1984).

\section{Evidence for neotenic morphotypes in branchiosaurids}

Schoch \& Milner (2008) recognized two distinct clades within Branchiosauridae, the Apateon-clade on the one hand and the Melanerpeton-clade on the other hand. The developmental pathway of metamorphosis is thus far exclusively known from the Apateon-clade and more specifically the species Apateon gracilis. In contrast, members of the Melanerpeton clade seem to be universally neotenic and several large specimens, likely representing adult neotenes are known for Melanerpeton humbergense (Boy, 1978) and Melanerpeton eisfeldi Werneburg, 1988 (A. Milner, pers. comm. 2008).

In addition to the adult Apateon gracilis specimen that passed through a series of developmental events finally transforming into clearly terrestrial adult animals (Schoch \& Fröbisch 2006), large specimens of Apateon pedestris and Apateon caducus have been recognized that lack these feature altogether. Nonetheless, they clearly differ from larval specimens and are identified as adult neotenes. The anatomical features associated with neoteny in branchiosaurids are discussed in detail on the basis of a very large, previously undescribed specimen of Apateon caducus.

Institutional abbreviations: BSP, Bayerische Staatsammlung für Paläontologie, München (Germany); GPIM, Institut für Geowissenschaften, Paläontologie, Universität Mainz (Germany).

\section{Description}

The specimen was collected at the Niederkirchen locality in the Pfalz region of southwestern Germany (Gzhelian). It is preserved on a slab and counter-slab (GPIMN-9u2 and GPIM-N-9u2a) (Figs 1A, B, 2A, B, 3) and represents a very large individual with a skull length of $38 \mathrm{~mm}$. The specimen consists of a well-preserved partial skeleton comprising the skull in dorsal and ventral views, as well as the anterior portion of the trunk and

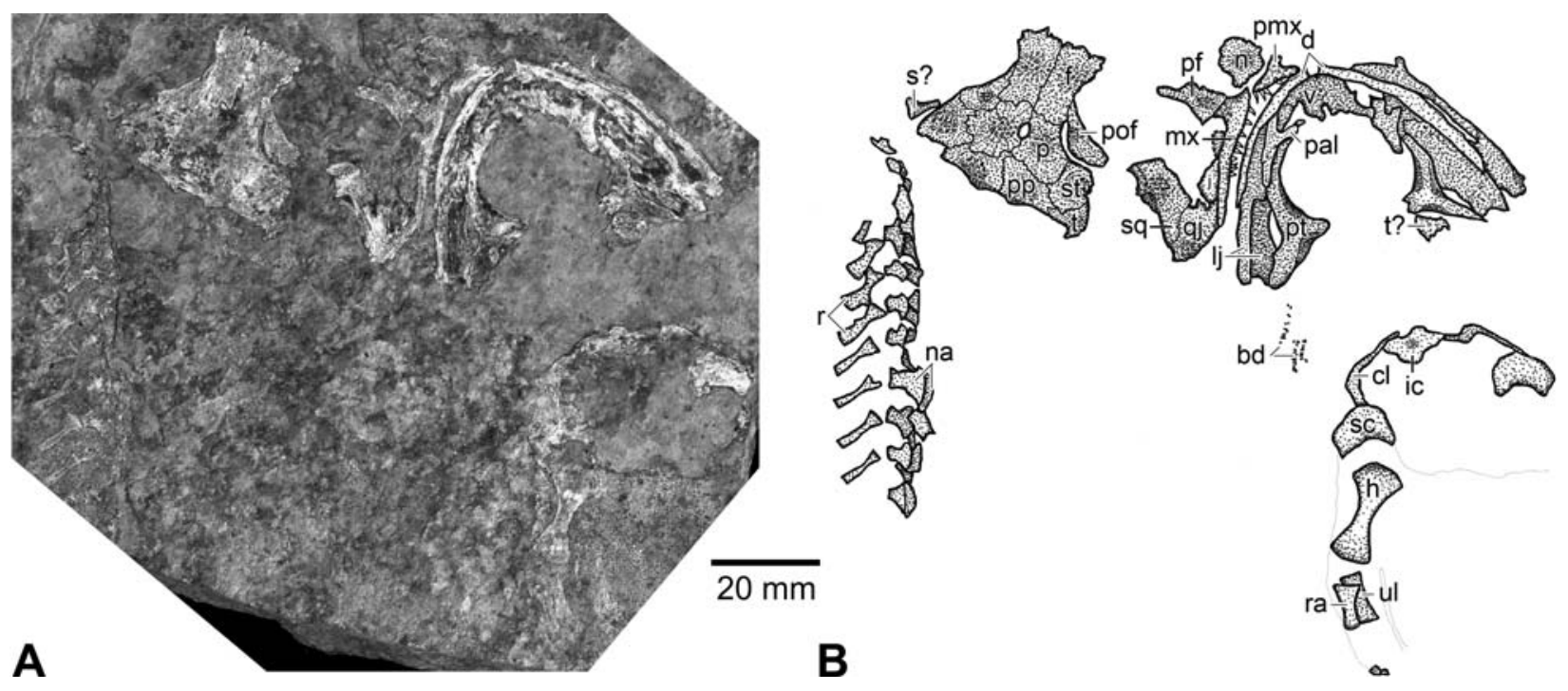

Figure 1. Apateon caducus (Ammon, 1889), specimen GPIM-N-9u. A. Photograph of specimen; B. Drawing of specimen. Abbreviations: bd - branchial denticles; cl - clavicle; d - dentary; h - humerus; ic - interclavicle; j - jugal; mc - metacarpals; mx maxilla; n - nasal; na - neural arch; pal - palatine; pmx - premaxilla; pf - prefrontal; ph - phalanges; pof - postfrontal; pt pterygoid; qj - quadratojugal; r - rib; ra - radius; s? - stapes?; sc - scapula; sq - squamosal; ul - ulna. 


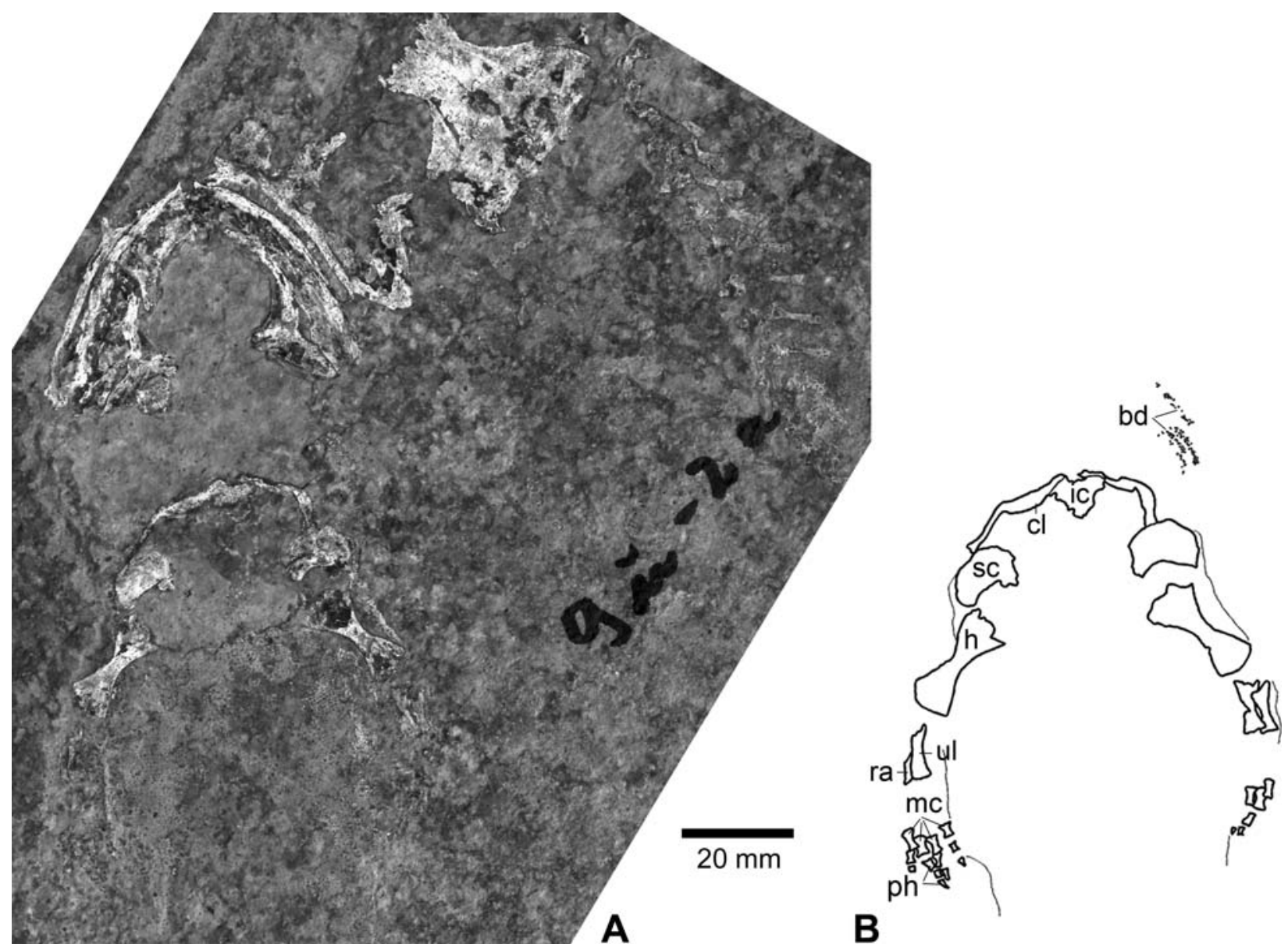

Figure 2. Apateon caducus (Ammon, 1889), specimen GPIM-N-9u a (counterslab). A. Photograph of specimen; B. Drawing of shoulder girdle and forelimbs. For an explanation of abbreviations see Figure 1.

the forelimbs. A 'skin shadow' is visible in the posterior region of the trunk, where faint impressions of the small scales that covered the body, are visible (Figs 1B, 2A).

GPIM-N-9u2 can be assigned to the species Apateon caducus on the basis of its wide skull roof (IOW/ $S_{1}=0.32$ ), the slender parietals, which are only slightly wider than the frontals, and the very wide, posteromedially extended postfrontals (Boy 1987; Schoch 1992) (Figs 1A, B, 3). Although the prefrontal is not preserved in place, pre- and postfrontal probably approached each other closely, because the anterior process of the postfrontal reaches far anteriorly alongside two-thirds of the length of the frontal and the prefrontal also shows a long posterior process (Figs 1A, B, 3). Pre- and postfrontal are clearly separated in larval A. caducus specimens, but approach each other in older individuals. Moreover, the robust palatine branch of the pterygoid is strongly arcuate, a feature that is also typically found in A. caducus (Boy 1987).

The well-preserved posterior portion of the skull in specimen GPIM-N-9u shows that it lacks any ossifications of the endocranium and the jaw articulation was at the level or only slightly posterior to the posterior end of the skull roof.
Rows of branchial denticles are preserved on the right lateral side of the specimen, located between the skull and the shoulder girdle (Figs 1,2). Ossified branchial denticles were positioned along the endochondral gill rakers with the latter providing a means to close the gill slits during suction feeding, thereby producing a greater negative pressure in the oral cavity. Branchial denticles on the gill rakers may have served as a filtering device in larvae (Schoch 2001, 2002b; Schoch \& Milner 2008). While soft tissue preservation of the external gills does not occur in this specimen, the presence of ossified branchial denticles clearly indicates that the animal had open gill clefts, which represent the most clear-cut anatomical evidence of an aquatic lifestyle in Paleozoic amphibians (Boy 1974; Schoch 2001, 2002b).

Changes in the ornamentation of the dermal skull roofing elements have frequently been suggested to be associated with metamorphosis in Paleozoic amphibians (Bystrow 1935; Boy 1974; Schoch 2001; Schoch \& Fröbisch 2006) and indeed metamorphosed specimens of Apateon gracilis display a pattern of pronounced polygonal ridges and grooves otherwise never found in branchiosaurids. In contrast, specimen GPIM-N-9u shows a pattern of dermal ornamentation that consists 


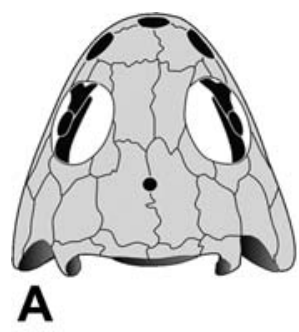
$\overline{10 \mathrm{~mm}}$

B
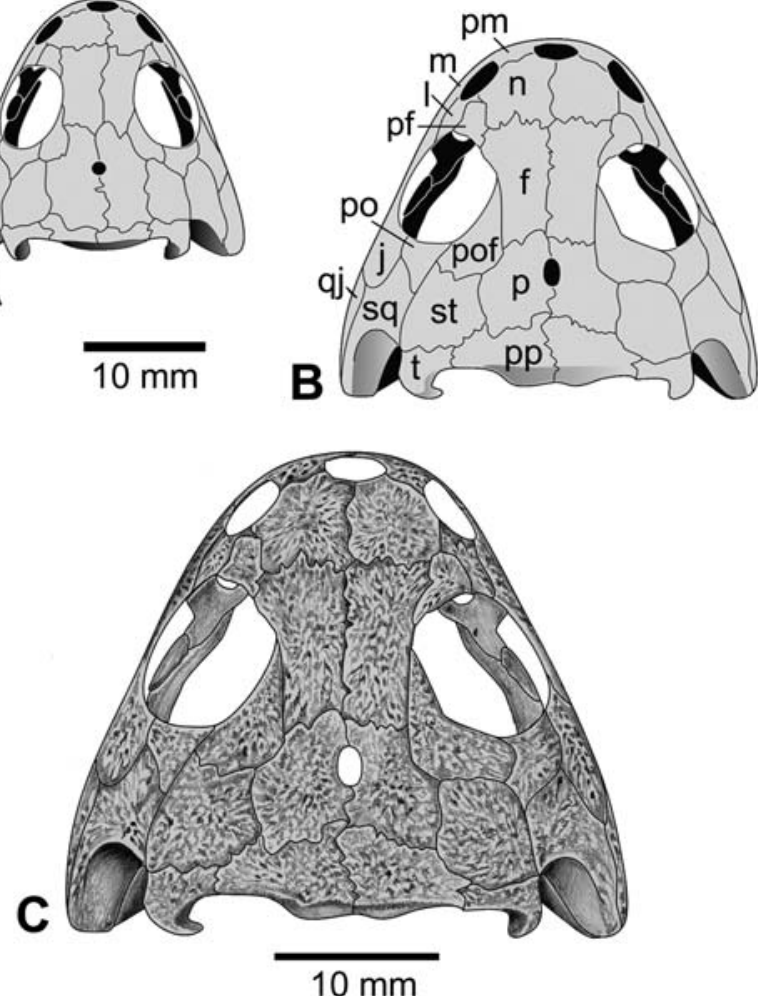

$10 \mathrm{~mm}$

Figure 3. Apateon caducus (Ammon, 1889). A. Previously largest known complete skull from the Erdesbach locality; B, C. Reconstruction of the large neotenic specimen from the Niederkirchen locality. Abbreviations: $\mathbf{f}-$ frontal; $\mathbf{j}-$ jugal; $\mathbf{l}-$ lacrimal; m - maxilla; $\mathbf{n}$ - nasal; $\mathbf{p}$ - parietal; pf - prefrontal; pm - premaxilla; po - postorbital; pof - postfrontal; pp postparietal; qj - quadratojugal; sq - squamosal; st - supratemporal; $\mathbf{t}$ - tabular.

of pits in the central parts of individual skull roofing bones and shallow grooves radiating out from this area, which represents and accentuated form of the larval dermal ornamentation (Figs 1A, B, 3).

The paired neural arches are the only ossified elements in the vertebral column with central elements presumably remaining unossified. Ossified intercentra are found only in metamorphosed specimens of the branchiosaurid Apateon gracilis.

The elements of the shoulder girdle are overall small with a small triangular interclavicle and slender clavicles and cleithra. The small, ossified, and crescentshaped scapular portion of the scapulacoracoid differs strongly from the large, bony scapulocoracoid plates present in metamorphosed Apateon gracilis. The radius and ulna of specimen GPIM-N-9u are well ossified and have widened condylar ends and slender shafts, but lack distinct processes and muscle attachment scars (Figs 1,2). All four metacarpals and digits of the right manus, as well as three metacarpals and three phalangeal elements of the left manus are preserved on slab GPIM-N 9u2a (Figs 2A, B). Metacarpals and phalanges are well ossified and the terminal phalanges have an arcuate, pyramidal form, typical for late ontogenetic stages of A. caducus and A. pedestris (Schoch 1992; Fröbisch et al. 2007). The carpals remained unossified, which is also commonly seen in neotenic salamanders. However, it remains unknown whether ossified carpal and tarsal elements are present in metamorphosed A. gracilis, because this region is not preserved in the available specimens. The high degree of ossification in the limb skeleton, with well-developed muscle attachment areas and an ossified olecranon process in metamorphosed A. gracilis indicate that metamorphs were primarily land-dwelling animals capable of an effective terrestrial locomotion. In a closely related group of small dissorophoid amphibians, the terrestrial Amphibamidae, carpals and tarsals are frequently ossified (e.g. Daly 1994; Schoch \& Rubidge 2005; Anderson et al. 2008) and it seems likely that the mesopodial region of metamorphosed branchiosaurids ossified as well. In comparison, the low degree of ossification and the lack of distinct processes and pronounced muscle attachment areas in the limb elements of specimen GPIM-N-9u contrasts strongly with the condition found in the metamorphs of $A$. gracilis. The appendicular skeleton, particularly the shoulder girdle, was overall weakly ossified and was most likely not suitable for effective support of a large branchiosaurid on land. Instead, adult $A$. $c a$ ducus presumably spent its life in an aquatic habitat, where most of its body weight was supported through the buoyancy of the water.

Interestingly, specimen GPIM-N-9u shows small uncinate processes on some of the ribs lateral and slightly distal to the widened rib head (Figs 1A, B, 2A). Uncinate processes have not been reported in either morphotype of branchiosaurids before. Large uncinate processes are known from other amphibian groups, e.g. the aquatic capitosaur Mastodonsaurus (Schoch 1999), Archegosaurus (Witzmann \& Schoch 2006), Sclerocephalus (Boy 1988), and Sclerothorax (Schoch et al. 2007). Although their functional importance is unclear, they usually formed in only adult specimens. Branchiosaurids had a rather short trunk and most probably did not rely on lateral undulation of the body for locomotion, whereby uncinate processes would have hindered the lateral movement. The tail, which bore a large fin as seen in many well-preserved specimens with soft tissue preservation (e.g. Werneburg 2002), served as the main tool for rapid propulsion in the aquatic environment, while the limbs might have been used for slow locomotion on the ground and for clinging to aquatic vegetation. The uncinate processes in specimen GPIM-N-9u possibly offered additional attachment areas for trunk musculature in large, adult neotenes.

\section{Discussion and conclusions}

With a skull length of $38 \mathrm{~mm}$, GPIM-N-9u represents the largest known specimen within the extensive collections of Apateon. The combination of features, i.e. the large size, partially interdigitating and tight sutures of the skull roof, the high degree of ossification and differentiation of the postcranium as compared to 
smaller larval specimens, and the presence of uncinate processes, indicates that this specimen represents an adult. However, it lacks ossifications of the exoccipitals and quadrates, intercentra, and the coracoid portion of the scapulocoracoid as seen in metamorphosed specimens of Apateon gracilis. Moreover, larval somatic features are retained, such as the ossified branchial denticles indicative of the presence of open gill slits and the accentuated larval-type sculpturing of the dermal skull roofing elements that demonstrate that this animal was an adult neotene and lived in an aquatic habitat.

The anatomical evidence at hand clearly indicates that both life history strategies, metamorphosis and neoteny, were established in Paleozoic branchiosaurids. However, the specimens identified as adult neotenes and metamorphs, belong to different species of Apateon, i.e. A. caducus and A. gracilis, respectively. Therefore, there is at this time no direct evidence that branchiosaurids utilized facultative neoteny within a single species (or even population) to accommodate to changing environmental conditions, as observed in many modern salamander taxa. Nonetheless, in analogy with modern urodeles it is probable that branchiosaurids at some point in their evolutionary history had a reaction norm with the full set of phenotypic responses to different environmental cues (metamorphosis to neoteny) and likely were facultatively neotenic. Later, the frequency of one of the phenotypes may have increased in different taxa/populations under stable environmental conditions and this phenotype afterward became fixed.

Branchiosaurids are found in central European fossil lakes, which during the Late Carboniferous and Early Permian were located in the Variscian Mountains at an altitude of up to 2000 meters (Becq-Giraudon et al. 1996; Boy \& Schindler 2000). Most of the lakes that yielded branchiosaurids were very large and deep lakes with up to tens of kilometers in diameter. Boy (1998, 2003) and Boy \& Sues (2000) reconstructed the paleoecological successions of some of the branchiosaurid bearing lakes of the Saar-Nahe Basin of western Germany. This showed that small branchiosaurids, in particular A. pedestris, were founder taxa, initially colonizing the lakes and later disappeared when fish or more specialized amphibian taxa appeared. However, some lakes with an impoverished pelagic community (e.g. the Odernheim and Ruthweiler lakes) do not show this succession and A. pedestris co-occurs with larger carnivorous taxa such as A. caducus and Melanerpeton humbergense. In the Niederkirchen lake, small branchiosaurids such as A.pedestris were found to initially co-occur with fish. Later, only the acanthodian Acanthodes remains as fish representative and in addition the larger branchiosaurids A. caducus and M. humbergense, and subsequently also the basal dissorophoid Micromelerpeton credneri Bulman \& Whittard, 1926 are present. Specimen GPIM-N-9u derives from the latest phase preserved in the succession of sediments (layer 9) of the Niederkirchen locality and inhabited the lake simul- taneously with acanthodians and other branchiosaurid taxa (J. Boy, pers. comm. 2008).

This shows that branchiosaurids inhabiting the different Paleozoic lakes were exposed to quite divergent environmental conditions within the aquatic environment, comparable to the factors that are known to influence the frequency of neotenes in modern salamander populations. Similar factors may also have influenced the development and frequency of neotenic and metamorphic morphotypes of different branchiosaurid populations, but despite their excellent fossil record it remains impossible to decipher specific environmental parameters that may have acted on the particular branchiosaurid populations. Boy (2003) found evidence for the amphibian populations in the Odernheim and Niederkirchen lakes to have been under stress, and that the genus Apateon was apparently the most successful vertebrate to cope with unfavorable conditions. The neotenic pathway permitted Apateon to respond to external parameters by (1) extending the early larval phase and stay a filter-feeder (A. pedestris) or (2) truncate the early phase, accelerate growth, consolidate the connection between the jaw and the cheek and form a larger predatory morphotype (A. caducus) (Schoch \& Milner 2008).

While the lakes were located in the paleoequatorial region, monsoon-like weather patterns have been reconstructed for this area in the Permo-Carboniferous (Patzowsky et al. 1991), resulting in significant variation in precipitation throughout the year (Clausing \& Boy 2000). In combination with the high altitude, this would at least seasonally produce harsh conditions in the terrestrial environment. The large size of the lakes suggests that they provided a permanent body of water over long periods of time providing a sheltered, stable environment for branchiosaurids and thereby promoting the development of neotenic morphotypes. Selection should only favor plasticity (i.e. facultative neoteny) if environmental conditions are sufficiently spatially or temporally variable (Whiteman 1994). If the lakes provided a constant favorable environment for branchiosaurids as opposed to the terrestrial habitat, it is possible that the frequency of neotenes increased rapidly, resulting in the dominance of this phenotype in the branchiosaurid fossil record.

Certain terrestrial adaptations in the branchiosaurid body plan, such the short trunk and long limbs suggest that branchiosaurids represent an initially terrestrial clade (Boy 1972; Boy \& Sues 2000). The occurrence of metamorphosed morphs in the phylogenetically highly nested taxon Apateon gracilis would therefore suggest a reversal to the metamorphosis trajectory in branchiosaurids (Schoch \& Milner 2008). However, there may be manifold ecological or seasonal/depositional reasons for a selection of fossil preservation against terrestrial adults (Boy \& Sues 2000). Therefore, the sparse fossil record of metamorphosed branchiosaurids and the apparently overwhelming number of neotenes may at least in part be a relic of the fossil record, providing only a biased and time averaged view 
of the evolution of branchiosaurid life history trajectories.

Nonetheless, an understanding of the patterns of life history trajectories in branchiosaurids provides important insights into the biology and evolution of this clade. Novel traits expressed as an alternative phenotype can undergo extensive evolution in a population and represent an important phase in the evolution of major adaptive novelties characterizing species and higher taxa (West-Eberhard 2003; Wiens et al. 2005). The plasticity in life history pathways of branchiosaurids may have played an important role for the evolutionary success and diversification of this Paleozoic amphibian clade.

\section{Acknowledgements}

We would like to thank Axel Friebe and Michael Wuttke for access to the original specimens housed at Freiberg and Mainz. Florian Witzmann, Ralf Werneburg, Jürgen Boy, Robert Carroll, and Hans Larsson are thanked for helpful discussions. Jörg Fröbisch read earlier versions of the manuscript and we thank him for his constructive suggestions. This project was funded by a graduate student award to NBF through a NSERC discovery grant to R. L. Carroll, McGill Graduate Student Fellowships, and the DFG grant 'Amphibien-Metamorphose' to RRS.

\section{References}

Ammon, L. von 1889. Die permischen Amphibien der Rheinpfalz. Straub, München.

Anderson, J. D. 1971. The life history and systematics of Ambystoma rosaceum. - Copeia 4: 371-377.

Anderson, J. S., Reisz, R. R., Scott, D., Fröbisch, N. B. \& Sumida, S. S. 2008. A stem batrachian from the Early Permian of Texas and the origin of frogs and salamanders. - Nature 453: 515-518.

Becq-Giraudon, J.-F., Montenat, C., \& Van den Driessche, J. 1996. Hercynian high-altitude phenomenan the French Massif Centrale: tectonic implications. - Paleogeography, Paleoclimatology, Paleoecology 122: 127-141.

Bolt, J. R. 1974. Evolution and functional interpretation of some suture patterns in Paleozoic labyrinthodont amphibians and lower tetrapods. - Journal of Paleontology 48: 434-458.

Boy, J. A. 1971. Zur Problematik der Branchiosaurier (Amphibia, Karbon - Perm). - Paläontologische Zeitschrift 45 (3/4): 107-119.

Boy, J. A. 1972. Die Branchiosaurier (Amphibia) des saarpfaelzischen Rotliegenden (Perm, SW-Deutschland). - Abhandlungen des hessischen Landesamt für Bodenforschung 65: 6-137.

Boy, J. A. 1974. Die Larven der rhachitomen Amphibien (Amphibia: Temnospondyli; Karbon-Trias). - Paläontologische Zeitschrift 48: 236-268.

Boy, J. A. 1978. Die Tetrapodenfauna (Amphibia, Reptilia) des saarpfälzischen Rotliegenden (Unter-Perm; SW-Deutschland). 1. Branchiosaurus. - Mainzer geowissenschaftliche Mitteilungen 7: 27-76.

Boy, J. A. 1986. Studien über die Branchiosauridae (Amphibia: Temnospondyli) 1. Neue und wenig bekannte Arten aus dem mitteleuropäischen Rotliegenden (?oberstes Karbon bis unteres Perm). - Paläontologische Zeitschrift 60: 131-166.

Boy, J. A. 1987. Studien über die Branchiosauridae (Amphibia: Temnospondyli; Ober-Karbon - Unter-Perm. Systematische Übersicht. - Neues Jahrbuch für Geologie und Paläontologie Abhandlungen 174 (1): 75-104.

Boy, J. A. 1988. Über einige Vertrteter der Eryopoidea (Amphibia: Temnospondyli) aus dem europäischen Rotliegend (? höchstes
Karbon-Perm). 1. Sclerocephalus. - Paläontologische Zeitschrift 62: 107-132.

Boy, J. A. 1998. Möglichkeiten und Grenzen einer Ökosystem-Rekonstruktion am Beispiel des lakustrinen Paläo-Ökosystems. 1. Theoretische und methodische Grundlagen. - Paläontologische Zeitschrift 72 (1/2): 207-240.

Boy, J. A. 2003. Paläoökologische Rekonstruktion von Wirbeltieren: Möglichkeiten und Grenzen. - Paläontologische Zeitschrift 77 (1): $123-152$.

Boy, J. A. \& Schindler, T. 2000. Ökostratigraphische Bioevents im Grenzbereich Stephanium/Autunium (höchstes Karbon) des SaarNahe-Beckens (SW-Deutschand) und benachbarter Gebiete. Neues Jahrbuch für Geologie und Paläontologie Abhandlungen 216 (1): 89-152.

Boy, J. A., \& Sues, H.-D. 2000. Branchiosaurs: Larvae, metamorphosis and heterochrony in temnospondyls and seymouriamorphs. In Heatwole, H. \& Carroll, R. L. (eds). Amphibian Biology, Volume 4, Palaeontology. Surrey Beatty \& Sons, Chipping Norton: pp. 1151-1197.

Bulman O. M. B. \& Whittard, W. F. 1926. On Branchiosaurus and allied genera (Amphibia). - Proceedings of the Zoological Society of London 1926: 533-579.

Bystrow, A. P. 1935. Morphologische Untersuchungen der Deckknochen des Schädels der Wirbeltiere, 1. Mitteilung: Schädel der Stegocephalen. - Acta Zoologica 16: 65-141.

Clausing, A., \& Boy, J. A. 2000. Lamination and primary production in fossil lakes: relationship to palaeoclimate in the CarboniferousPermian transition. In Hart, M. B. (ed.). Climates: Past and Present. Geological Society, London: pp. 5-16.

Credner, H. 1881. Die Stegocephalen (Labyrinthodonten) aus dem Rothliegenden des Plauenschen Grundes. 2. Theil. - Zeitschrift der Deutschen geologischen Gesellschaft 33: 298-330.

Daly, E. 1994. The Amphibamidae (Amphibia: Temnospondyli), with a description of a new genus from the Upper Pennsylvanian of Kansas. - The University of Kansas Miscellaneous Publications 85: 1-59.

Denoel, M., Hervant, F., Schabetsberger, R. \& Joly, P. 2002. Shortand long-term advantages of an alternative ontogenetic pathway. - Biological Journal of the Linnean Society 77: 105-112.

Duellman, W. E., \& Trueb, L. 1986. Biology of amphibians. McGrawHill Book Co., New York

Fröbisch, N. B., Carroll, R. L. \& Schoch, R. R. 2007. Limb ossification in the Paleozoic branchiosaurid Apateon (Temnospondyli) and the early evolution of preaxial dominance in tetrapod limb development. - Evolution \& Development 9 (1): 69-75.

Green, J. 1825. Description of a new species of salamander. - Journal of the Academy of Natural Sciences Philadelphia 5: 116.

Harris, R. N. 1987. Density-dependent paedomorphosis in the salamander Notophthalmus viridescens dorsalis. - Ecology 68 (3): $705-712$.

Harris, R. N. 1989. Ontogenetic change in size and shape of the faculatively paedomorphic salamander Notophthalmus viridescens. Copeia 1989 (1): 35-42.

Harris, R. N., Semlitsch, R. D., Wilbur, H. M. \& Fauth, J. E. 1990. Local variation in the genetic basis of paedomorphosis in the salamander Ambystoma talpoideum. - Evolution 44 (6): 1588-1630.

Meyer, H. von 1844. Briefliche Mitteilungen and Prof. Bronn. Neues Jahrbuch für Mineralogie, Geognosie, Geologie und Petrefaktenkunde 1844: 336-337.

Milner, A. R. 1982. Small temnospondyl amphibians from the middle Pennsylvanian of Illinois. - Paleontology 25 (3): 635-664.

Patterson, K. K. 1978. Life history aspects of paedogenic populations of the mole salamander Ambystoma talpoideum. - Copeia 1978 (4): 649-655.

Patzowsky, M. E., Smith, L. H., Markwick, P. J., Engberts, C. J. \& Gyllenhaal, E. D. 1991. Application of the Fujita-Ziegler paleoclimate model: Early Permian and Late Cretaceous examples. - Paleogeography, Paleoclimatology, Paleoecology 86: 67-85. 
Rafinesque, C. S. 1820. Annals of nature or annual synopsis of new genera and species of animals, plants, etc. discovered in North America. Thomas Smith, Lexington (Kentucky).

Schoch, R. R. 1992. Comparative ontogeny of early Permian branchiosaurid amphibians from southwestern Germany. - Palaeontographica, Abteilung A 222: 43-83.

Schoch, R. R. 1995. Heterochrony in the development of the amphibian head. In McNamara, K. J. (ed.). Evolutionary change and heterochrony. John Wiley \& Sons Ltd., New York: pp. 107-124.

Schoch, R. R. 1999. Comparative osteology of Mastodonsaurus giganteus (Jaeger, 1828) from the Middle Triassic (Lettenkeuper: Longobardian) of Germany (Baden-Würtemberg, Bayern, Thüringen). - Stuttgarter Beiträge zur Naturkunde 278: 1-175.

Schoch, R. R. 2001. Can metamorphosis be recognized in Paleozoic amphibians? - Neues Jahrbuch für Geologie und Paläontologie Abhandlungen 220 (3): 335-367.

Schoch, R. R. 2002a. The early formation of the skull in extant and Paleozoic amphibians. - Paleobiology 28 (2): 278-296.

Schoch, R. R. 2002b. The evolution of metamorphosis in temnospondyls. - Lethaia 35: 309-327.

Schoch, R. R. 2004. Skeleton formation in the Branchiosauridae: a case study in comparing ontogenetic trajectories. - Journal of Vertebrate Paleontology 24: 309-319.

Schoch, R. R. \& Carroll, R. L. 2003. Ontogenetic evidence for the Paleozoic ancestry of salamanders. - Evolution \& Development 5 (3): 314-324.

Schoch, R. R. \& Rubidge, B. S. 2005. The amphibamid Micropholis from the Lystrosaurus Assemblage Zone of South Africa. - Journal of Vertebrate Paleontology 25 (3): 502-522.

Schoch, R. R. \& Fröbisch, N. B. 2006. Metamorphosis and neoteny: alternative pathways in an extinct amphibian clade. - Evolution 60 (7): 1467-1475.

Schoch, R. R., Fastnacht, M., Fichter, J. \& Keller, T. 2007. Anatomy and relationships of the Triassic temnospondyl Sclerothorax. Acta Palaeontologica Polonica 52: 117-136.

Schoch, R. R. \& Milner, A. R. 2008. The intrarelationships and evolutionary history of the temnospondyl family Branchiosauridae. Systematic Palaeontology 6 (4): 409-431.

Semlitsch, R. D. \& Gibbons, J. W. 1985. Phenotypic variation in metamorphosis and paedomorphosis in the salamander Ambystoma talpoideum. - Ecology 66 (4): 1123-1130.

Semlitsch, R. D., Harris, R. N. \& Wilbur, H. M. 1990. Paedomorphosis in Ambystoma talpoideum: Maintanance of population variation and alternative life-history pathways. - Evolution 44 (6): $1604-1613$
Shaffer, H. B. 1984. Evolution in a paedomorphic lineage. II. Allometry and form in the Mexican ambystomatid salamanders. - Evolution 38: 1207-1218.

Shaffer, H. B. \& Voss, S. R. 1996. Phylogenetic and mechanistic analysis of a developmentally integrated character complex: Alternative life history modes in ambystomatid salamanders. - American Zoologist 36: 24-35.

Shaw, G. \& Nodder, F. P. 1789. The Naturalist's Miscellany, or coloured figures of natural objects; drawn and described from nature. Vol. 9. London.

Snyder, R. C. 1956. Comparative features of the life histories of Ambystoma gracile (Baird) from populations at low and high altitudes. - Copeia 1: 41-50.

Sprules, W. G. 1974. The adaptive significance of paedogenesis in North American species of Ambystoma (Amphibia: Caudata): an hypothesis. - Canadian Journal of Zoology 52 (1974): 393-400

Tihen, J. A. 1942. A colony of fossil neotenic A. tigrinum. - University of Kansas Science Bulletin 28: 189-198.

Werneburg, R. 1988. Die Stegocephalen der Goldlauterer Schichten (Unterrotliegendes, Unterperm), Teil II: Apateon kontheri n. sp., Melanerpeton eisfeldi $\mathrm{n}$. sp. des Thüringer Waldes und andere. Freiberger Forschungshefte C 427: 7-23.

Werneburg, R. 1991. Die Branchiosaurier aus dem Unterrotliegend des Döhlener Beckens bei Dresden. - Veröffentlichungen des Naturhistorischen Museum Schleusingen 6: 75-99.

Werneburg, R. 2002. Apateon dracyiensis - eine frühe Pionierform aus dem europäischen Rotliegend, Teil 2: Paläoökologie. - Veröffentlichungen des Naturhistorischen Museum Schleusingen 17: 17-32.

Werneburg, R. \& Schneider, J. W. 2006. Amphibian biostratigraphy of the European Permo-Carboniferous. In Lucas, S. G., Cassinis, G. \& Schneider, J. W. (eds). Non-marine Permian Biostratigraphy and Biochronology. The Geological Society of London Special Publications, London 265: 201-215.

West-Eberhard, M. J. 2003. Developmental plasticity and evolution. Oxford University Press, New York.

Whiteman, H. 1994. Evolution of facultative paedomorphosis in salamanders. - The Quarterly Review of Biology 69 (2): 205-221.

Wiens, J. J., Bonett, R. M. \& Chippindale, P. T. 2005. Ontogeny discombobulates phylogeny. - Systematic Biology 54 (5): 91-110.

Wilbur, H. M. \& Collins, J. P. 1973. Ecological aspects of amphibian metamorphosis. - Science 182: 1305-1314.

Witzmann, F. \& Schoch R. R. 2006. The postcranium of Archegosaurus decheni, and a phylogenetic analysis of temnospondyl postcrania. - Palaeontology 49: 1211-1235. 